\title{
The growth performance and resistance to salinity stress of striped catfish Pangasius sp. juvenile in biofloc system with different feeding rates
}

\section{Kinerja pertumbuhan dan ketahanan benih ikan patin terhadap stres salinitas dalam sistem bioflok dengan tingkat pakan berbeda}

\author{
Wellya Wichi Merithaํㅜ, Muhammad Agus Suprayudi', Julie Ekasari ${ }^{*}$ \\ 'Department of Aquaculture, Faculty of Fisheries and Marine Science, Bogor Agricultural University, \\ Bogor, West Java 16680 \\ *Email: j_ekasari@ipb.ac.id
}

(Received February 9, 2017; Accepted July 30, 2018)

\begin{abstract}
This study aimed to evaluate the growth performance and resistance to salinity stress of striped catfish juvenile reared in biofloc with different feeding rate (FR). The treatments applied in this study were rearing the fish in biofloc with FR 5\% and $8 \%$ of biomass per day, and rearing the fish with a FR of $8 \%$ per day without biofloc system as the control. The fish with an initial average length of $1.81 \pm 0.20 \mathrm{~cm}$ were stocked in 9 units of $50 \mathrm{~L}$ aquaria with density of $40 \mathrm{ind} /$ aquaria $\left(800 \mathrm{ind} / \mathrm{m}^{3}\right)$ for 15 days rearing period. In biofloc systems, the addition of tapioca as a source of organic carbon was done every day with an estimated $\mathrm{C} / \mathrm{N}$ ratio of 10 . No water exchange was done in biofloc systems, whereas regular water exchange was applied in the control. Results of the experiment showed that survival was not significantly different amongst treatments $(\mathrm{P}>0.05)$. However, the specific growth rate of the fish in biofloc system with a FR of $8 \%$ per day showed the highest value and was significantly different from other treatments $(\mathrm{P}<0.05)$. Fish reared in biofloc system tend to have lower feed conversion ratios (FCRs) than the control. The lowest FCR was found in fish reared in biofloc system with 5\% FR and significantly lower than control $(\mathrm{P}<0.05)$. Salinity stress test was conducted by soaking 15 juveniles in water with a salinity of $20 \mathrm{~g} / \mathrm{L}$ for an hour. The survival of fish after salinity stress test were significantly higher for fish reared in bifloc system than control $(\mathrm{P}<0.05)$. These datas showed that rearing striped catfish juvenile in biofloc system could reduce FCR, increase the growth and robustness of fish.
\end{abstract}

Keywords: biofloc, feeding rate, growth, salinity stress test, striped catfish

\begin{abstract}
ABSTRAK
Penelitian ini bertujuan untuk mengevaluasi kinerja pertumbuhan dan ketahanan benih ikan patin terhadap stres salinitas yang dipelihara dalam sistem bioflok dengan tingkat pemberian pakan (FR) berbeda. Perlakuan yang terdapat dalam penelitian ini adalah benih patin yang dipelihara dalam sistem bioflok dengan FR 5\% dan 8\% per hari, dan pemeliharaan benih dengan FR $8 \%$ per hari tanpa penambahan sumber karbon sebagai kontrol. Benih patin dengan panjang rata-rata awal $1,81 \pm 0,20 \mathrm{~cm}$ dipelihara dalam 9 unit akuarium dengan volume air $50 \mathrm{~L}$ dan kepadatan 40 ekor/akuarium $\left(800 \mathrm{ekor} / \mathrm{m}^{3}\right)$ selama 15 hari. Pada sistem bioflok, penambahan tapioka sebagai sumber karbon dilakukan setiap hari dengan C/N 10. Pada sistem bioflok tidak dilakukan pergantian air, sedangkan pada kontrol dilakukan pergantian air. Kelangsungan hidup ikan tidak berbeda nyata antar perlakuan. Namun, tingkat pertumbuhan spesifik ikan dalam sistem bioflok dengan FR 8\% per hari menunjukkan nilai tertinggi dan berbeda nyata antar perlakuan $(\mathrm{P}<0,05)$. Benih yang dipelihara pada sistem bioflok memiliki rasio konversi pakan (FCR) yang lebih rendah dibandingkan kontrol, namun tidak terdapat perbedaan yang signifikan antara perlakuan bioflok $(\mathrm{P}>0,05)$. Uji stres salinitas dilakukan dengan merendam 15 ekor benih patin pada air dengan salinitas 20 $\mathrm{g} / \mathrm{L}$ selama satu jam. Kelangsungan hidup setelah uji stres salinitas dari benih yang dipelihara di bioflok secara signifikan lebih tinggi dibandingkan kontrol $(\mathrm{P}<0,05)$. Hasil penelitian menunjukkan bahwa pemeliharaan benih patin pada sistem bioflok dapat menurunkan FCR, dan meningkatkan pertumbuhan dan ketahanan ikan terhadap stres salinitas.
\end{abstract}




\section{INTRODUCTION}

Striped catfish Pangasius sp. is one of the leading freshwater commodities that has a high economical value. Although the production of this fish has been increasing year to year, there are still some problems in the nursery production of striped catfish, including high susceptibility to environmental stressor and diseases. One of the environmental stressor that commonly occur in an aquaculture system is the high accumulation of ammonia affected by the feed quality and feeding management.

Biofloc technology is one of the current technology developed in aquaculture. The basic principle of biofloc technology is the heterotrophic microbial conversion of ammonia (and other nutrients) into microbial biomass that can be consumed by the cultured organism (Avnimelech, 2012; Ekasari, 2009). The conversion of ammonia and other toxic waste into microbial biomass could maintain the concentrations of these toxic compounds at minimum level, thus providing better environment for the cultured fish (Zhao et al., 2012). Meanwhile, the microbial biomass generated in this system could be directly consumed by the fish improving the feed utilization efficiency. Previous studies showed that rearing fish in the biofloc systems might bring benefits including higher growth performance (Kamilya, 2017), higher reproductive performance (Emilie et al., 2016), and higher immunity against diseases and environmental stress (Ekasari et al., 2015). In this context, the present study aimed to evaluate the growth performance and resistance to salinity stress of striped catfish juvenile that reared in biofloc system with different feeding rate.

\section{MATERIALS AND METHODS}

\section{Experimental design}

The experiment consisted of three treatments in triplicates, i.e. control (without biofloc at a feeding rate of $8 \%(\mathrm{~K}-8 \%)$ ), biofloc system with a feeding rate of $8 \%$ (BF-8\%), and biofloc system with a feeding rate of $5 \%(\mathrm{BF}-5 \%)$.

\section{Fish rearing}

The experiment was located in Department of Aquaculture, Faculty of Fisheries and Marine Science, Bogor Agricultural University, on March to April 2016. Striped catfish (Pangasius sp.) juveniles were obtained from local hatchery in Bogor, West Java, Indonesia and were acclimatized for a week prior to the on set of the experiment. The experiment was carried out in nine units of aquaria $(50 \mathrm{~cm} \times 40 \mathrm{~cm} \times 35 \mathrm{~cm})$ with stagnant water. Fish juveniles with an initial length of $1.81 \pm 0.20 \mathrm{~cm}$ and initial body weight of $80 \pm$ $40 \mathrm{mg}$ were randomly distributed into the aquaria at a density of $40 \mathrm{ind} /$ aquarium $\left(800 \mathrm{ind} / \mathrm{m}^{3}\right)$, and reared for 15 days. Commercial compounded feed containing $39-41 \%$ of protein was delivered three times a day with a feeding rate according to the treatments, i.e. $8 \%$ and $5 \%$ of the fish biomass/ day, respectively. Tapioca containing $40 \%$ of carbon (C) as the organic carbon source was added daily at a dose depending on the amount of feed given per day to obtain $\mathrm{C} / \mathrm{N}$ ratio of 10 . Commercial probiotic containing Bacillus subtilis and Bacillus licheniformis with concentration of $5 \times 10^{10} \mathrm{CFU} / \mathrm{g}$ was added into aquaria as much as $10 \mathrm{mg} / \mathrm{L}$ of concentration. Biofloc was appeared after 5 days of fish maintenance. At the end of the experiment, some samples of biofloc in each aquaria was collected by using a plankton net $(80$ $\mu \mathrm{m})$ for proximate analysis. Proximate analysis of biofloc consisted of protein, lipid, fiber, ash, and NFE. Protein analysis was performed with Kjeldhal method, lipid with Folch method, ash with gravimetric method, and fiber was measured by dissolving the biofloc sample with strong acid and base. Proximate compositions of biofloc were determined according to Takeuchi (1988).

\section{Water quality maintenance}

Water replacement was conducted only in control at a level of $10 \%$ every two days. Water quality parameters were measured once in a week including temperature, dissolved oxygen (DO), $\mathrm{pH}$, total ammonia nitrogen (TAN), nitrite, and nitrate concentrations. Temperature was measured using a thermometer, whereas $\mathrm{pH}$ and DO were measured using portable $\mathrm{pH}$ meter and DO meter, respectively. Total ammonia nitrogen was measured according to the standard procedure described in the standard for water and wastewater quality analyses (APHA, 2005).

\section{Juvenile quality assessment}

After 15 days of rearing, the survived juvenile was counted and measured to determine the final body weight and length and used to calculate condition factor (CF). To assess the robustness, the juveniles were soaked in water with $20 \mathrm{~g} / \mathrm{L}$ salinity for an hour and then transferred back into freshwater for an hour (Ekasari et al., 2015). The survivors were subsequently counted. 


\section{Parameters observed}

Survival

Survival rate (SR) was calculated with this following formula:

$$
\mathrm{SR}(\%)=\frac{\mathrm{Nt}}{\mathrm{No}} \times 100
$$

Note:

SR : Survival rate (\%)

$\mathrm{N}_{\mathrm{t}} \quad$ : The number of alive fish at the final observation (individual)

No: The number of the alive fish at the initial observation (individual)

Specific growth rate

Specific growth rate (SGR) was calculated by using this formula:

Note:

$$
\operatorname{SGR}(\%)=\left[\sqrt[t]{\frac{W t}{W o}}-1\right] \times 100
$$

SGR : Specific growth rate (\%/day)

$\mathrm{W}_{\mathrm{t}}$ : The average weight of the fish at the final observation $(\mathrm{g})$

$\mathrm{W}_{0} \quad$ : The average weight of the fish at the initial observation $(\mathrm{g})$

\section{Absolute length}

Absolute length was calculated by using this following formula:

$$
\mathrm{L}=\mathrm{L}_{\mathrm{t}}-\mathrm{L}_{0}
$$

Note:

L : Absolute length $(\mathrm{cm})$

$\mathrm{L}_{\mathrm{t}} \quad$ : The average length of the fish at the end of the study $(\mathrm{cm})$

Lo : The average length of the fish at the beginning of the study $(\mathrm{cm})$

\section{Condition factor}

Condition factor $(\mathrm{CF})$ was calculated according to the following formula:

$$
\mathrm{CF}=\mathrm{WL}^{-3} \times 100
$$

Note:

$\mathrm{CF}$ : Condition factor

W : The average weight of the fish at the end of the study $(\mathrm{g})$

L : The average length of the fish at the end of the study $(\mathrm{cm})$

$-3 \quad$ : Length coefficient to ensure that the value of $\mathrm{CF}$ to be worth 1 .

\section{Length coefficient of variation}

Length coefficient of variation was calculated using this following formula:

$$
\mathrm{VC}=(\mathrm{s} / \mathrm{y}) \times 100
$$

Note:

VC : Length coefficient of variation (\%)

s : Standard deviation

y : Mean of the length

\section{Feed conversion ratio}

Feed conversion ratio (FCR) was calculated using the formula:

$$
\mathrm{FCR}=\frac{\text { Feed consumed by fish }}{\mathrm{W}_{\mathrm{t}}+\mathrm{W}_{\mathrm{d}}-\mathrm{W}_{0}}
$$

Note:

FCR : Feed conversion ratio

$\mathrm{W}_{\mathrm{t}} \quad$ : Total weight of alive fish at the end of the study (g)

$\mathrm{W}_{\mathrm{d}} \quad$ : Total weight of dead fish at the end of the study (g)

$\mathrm{W}_{0} \quad$ : Total weight of fish at the beginning of the study (g)

\section{Protein efficiency ratio}

Protein efficiency ratio was calculated using this following formula:

$$
\text { PER }=\frac{W_{t}-W_{0}}{P_{i}} \times 100
$$

Note:

PER : Protein efficiency ratio

$\mathrm{W}_{\mathrm{t}} \quad$ : Total weight of fish at the final observation $(\mathrm{g})$

$\mathrm{W}_{0} \quad$ : Total weight of fish at the initial observation $(\mathrm{g})$

$\mathrm{Pi} \quad$ : Protein content of feed (\%)

\section{Data analysis}

Survival data was arcsin transformed. Homoscedasticity and normality of the data were assessed using Levene's test and KolmogorovSmirnov test, respectively. All data were showing homoscedastic, except for length coefficient of variation, and it was assessed using a nonparametric test, Kruskal-Wallis test. A oneway analysis of variance (ANOVA) followed by a post hoc Duncan's test (P level of 0.05) was performed on all data, except length coefficient of variation, water quality, and proximate composition of biofloc were used descriptive analysis. 


\section{RESULTS AND DISCUSSION}

\section{Results}

The survival of the juveniles in BF- $8 \%$ and BF-5\% were not significantly difference from that of the control at a range of $94.2 \%$ to $97.5 \%(\mathrm{P}>0.05)$ (Table 1). The specific growth rate of striped catfish juvenile in BF-5\% was significant lower than that of treatments BF- $8 \%$, but not significantly different from the control. There were no significant differences observed in the length and size coefficient of variance of the juvenile among treatments $(\mathrm{P}>0.05)$. The condition factor value of $\mathrm{BF}-8 \%$ was higher than those of the control and $\mathrm{BF}-5 \%$ at a range $1.33-1.45$, but not significantly different among treatments $(\mathrm{P}>0.05)$. The feed conversion ratios (FCR) of the fish in biofloc systems were lower than that of the control, and FCR in BF-5\% was significantly different from the control $(\mathrm{P}<0.05)$. The protein efficiency ratio of juvenile in control was not significantly different between treatments $(\mathrm{P}>0.05)$.

The immunity of striped catfish juvenile in BF-8\% and BF-5\% after salinity stress test were higher than the control $(\mathrm{P}<0.05)$. Water quality in all treatments was generally comparable and was within acceptable ranges for fish rearing (Table 2). The bioflocs collected from treatment BF-8\% has a higher levels of protein, lipid, fiber, and ash than that collected from treatment BF 5\% (Table $3)$.

\section{Discussion}

Most of previous studies related to the application of biofloc technology in fish or shrimp culture reported an increasing growth performance. In this study, the growth performance of striped catfish reared in biofloc system at the same feeding rate was higher than the control. Interestingly, the growth performance of the fish reared in biofloc system with feeding rate of 5\%/day was comparable to the control with feeding rate of $8 \% /$ day. This data indicated that in biofloc system, the fish has access to other food source, i.e. bioflocs, so that external feeding could be reduced.

In the marketing of striped catfish juvenile, size is one of the parameter that determines the quality of juvenile (May et al., 2011). In this study, the size variation was represented by length coefficient of variation, which was not significantly different among treatments. The

Table 1. Survival, specific growth rate (SGR), absolute lenght, condition factor (CF), length coefficient of variation, feed conversion ratio (FCR), and protein efficiency ratio of striped catfish in control and biofloc systems.

\begin{tabular}{cccc}
\hline Parameter & \multicolumn{3}{c}{ Treatment } \\
\cline { 2 - 4 } & K-8\% & BF-8\% & BF-5\% \\
\hline SR (\%) & $95 \pm 5^{\mathrm{a}}$ & $94.2 \pm 2.89^{\mathrm{a}}$ & $97.5 \pm 0^{\mathrm{a}}$ \\
SGR (\%/day) & $5.69 \pm 0,22^{\mathrm{ab}}$ & $6.83 \pm 0.99^{\mathrm{b}}$ & $5.27 \pm 0.61^{\mathrm{a}}$ \\
Absolute length (cm) & $0.58 \pm 0.05^{\mathrm{a}}$ & $0.65 \pm 0.10^{\mathrm{a}}$ & $0.54 \pm 0.05^{\mathrm{a}}$ \\
CF & $1.33^{\mathrm{a}}$ & $1.45^{\mathrm{a}}$ & $1.33^{\mathrm{a}}$ \\
Length coefficient of variation (\%) & $12.44 \pm 2.95^{\mathrm{a}}$ & $13.81 \pm 2.41^{\mathrm{a}}$ & $12.82 \pm 0.29^{\mathrm{a}}$ \\
FCR & $0.71 \pm 0.09^{\mathrm{b}}$ & $0.56 \pm 0.09^{\mathrm{ab}}$ & $0.51 \pm 0.07^{\mathrm{a}}$ \\
Protein efficiency ratio (\%) & $3.47 \pm 0.46^{\mathrm{a}}$ & $4.42 \pm 0.84^{\mathrm{a}}$ & $4.77 \pm 0.65^{\mathrm{a}}$ \\
\hline
\end{tabular}

Note: The value followed by different superscript in the same row indicates significantly different $(\mathrm{P}<0.05)$

Table 2. Range of water quality parameters during 15 days of rearing striped catfish juvenile in biofloc system and control.

\begin{tabular}{ccccc}
\hline \multirow{2}{*}{ Parameters } & \multicolumn{3}{c}{} & \multirow{2}{*}{ Reference } \\
\cline { 2 - 4 } & K-8\% & BF-8\% & BF-5\% & \\
\hline Temperature $\left({ }^{\circ} \mathrm{C}\right)$ & $26.8-27.9$ & $26.9-27.9$ & $26.8-27.9$ & $27-29$ (Tucker \& Robinson, 1990) \\
DO $(\mathrm{mg} / \mathrm{L})$ & $5.1-7.7$ & $5.2-7.8$ & $5.6-7.5$ & $>4$ (Murjani, 2011) \\
pH & $6.83-7.68$ & $6.95-7.74$ & $7.13-7.76$ & $6.5-9$ (Zweig et al., 1999) \\
TAN $(\mathrm{mg} / \mathrm{L})$ & $0.01-0.56$ & $0.01-0.72$ & $0.04-0.47$ & $<1.0$ (Lawson, 1995) \\
Nitrite $(\mathrm{mg} / \mathrm{L})$ & $0.02-0.33$ & $0.01-0.33$ & $0.02-0.30$ & $<0.5$ (Masser et al., 1992) \\
Nitrate $(\mathrm{mg} / \mathrm{L})$ & $0.89-1.00$ & $0.75-0.91$ & $0.70-1.11$ & $0-3.0$ (Lawson, 1995) \\
\hline
\end{tabular}




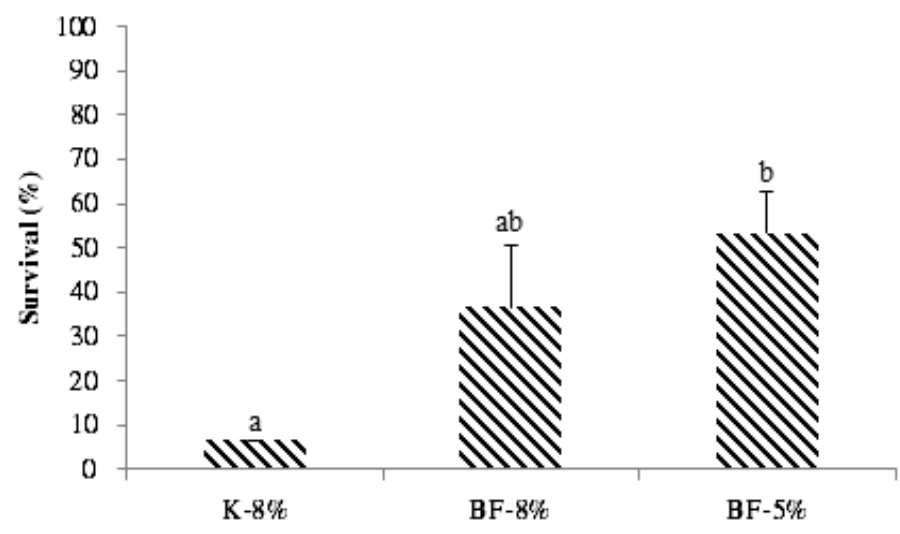

Figure 1. Survival of striped catfish juvenile from biofloc and control system after salinity stress test. Note: The value followed by different superscript above the bar chart indicates significantly different $(\mathrm{P}<0.05)$.

Table 3. Proximate compositions of biofloc from BF-8\% and Bf-5\% treatments

\begin{tabular}{cccc}
\hline $\begin{array}{c}\text { Proximate composition } \\
(\% \text { dry weight })\end{array}$ & BF-8\% & BF-5\% & Reference (Ekasari, 2014) \\
\cline { 3 - 4 } Protein & $48.07 \pm 7.76$ & $41.64 \pm 24.45$ & $14-58$ \\
Lipid & $9.85 \pm 2.84$ & $9.33 \pm 1.90$ & $<0.1-9$ \\
Fiber & $9.67 \pm 4.55$ & $9.54 \pm 3.73$ & - \\
Ash & $27.52 \pm 4.90$ & $20.85 \pm 4.86$ & $7-49$ \\
NFE & $4.89 \pm 21.73$ & $18.64 \pm 13.67$ & $14-54$ \\
\hline
\end{tabular}

value, however was less than $20 \%$ indicating the low size variability (Baras et al., 2011).

Feed conversion ratio is a zootechnical parameter used to evaluate feed utilization efficiency. Based on the result of this study, the juveniles reared in biofloc system showed lower FCR than the control system. Interestingly, the FCR of treatment with the lowest feeding rate (5\%) was the lowest, indicating the high efficiency of feeding in this particular treatment. Furthermore, the juvenile reared in BF-5\% seems to have higher protein efficiency ratio than the control, however, it was not significantly different. Overall, the data suggest that rearing the fish in biofloc system enhance the fish growth performance and feed utilization efficiency. Other study showed that biofloc could improve growth performance and feed utilization of shrimp (Xu \& Pan, 2012).

This positive effect of biofloc systems may be related to the nutritional contribution of biofloc as an additional food source for fish, which was continuously available in the culture system (Zhao et al., 2012; Crab et al., 2010; Wei et al., 2016). From the nutritional point of view, bioflocs nutrition may be considered as a good food source for fish. The nutritional composition of bioflocs may be varied and influenced by various factors such as carbon source (Ekasari et al., 2010; Ekasari et al., 2014), and microbial composition
(Ju et al., 2008). Nonetheless, the protein content of bioflocs in the present study was considerably high, at a range of $42 \%$ to $48 \%$ compared to that reported in previous studies which may range from 14-58\% (Ekasari, 2014). Ekasari et al. (2014) suggested that according to the amino acids composition, bioflocs could be considered as good protein source for shrimp, and sufficient protein source for tilapia. The bioflocs in the present study was also high in lipid content. Other study showed that bioflocs contained considerable levels of essential fatty acids such as arachidonic acid (Ekasari et al., 2010).

The immunity of juvenile reared in biofloc systems to salinity stress were higher than that of the control system. The previous study reported that biofloc could increase the immune protection and improvement of tolerance to environmental stress (Ekasari et al., 2015). The high immunity of the fish against environmental stress might be related to the nutritional contribution of bioflocs that improve the fish antioxidative capacity such as vitamin C and carotenoids (Crab et al., 2012; $\mathrm{Ju}$ et al., 2008). Xu and Pan (2013) reported that culturing Pacific white shrimp in biofloc system resulted in higher antioxidative capacity that improved the shrimp resistance against environmental stress and diseases infection.

Although water exchange was not performed 
in the biofloc system, the water quality in these systems was comparable to that of the control with regular water exchange and was still in optimal range for fish rearing. Similar effects of biofloc systems on water quality in aquaculture systems have been reported in previous studies including in shrimp (Lara et al., 2016) and tilapia (de Alvarenga et al., 2017; Long et al., 2015; Crab et al., 2009).

\section{CONCLUSION}

This study showed that rearing striped catfish juvenile in biofloc system could reduce the feeding rate from $8 \%$ to $5 \%$ per day without any adverse effect on the fish growth and survival, and could increase the fish robustness against salinity stress.

\section{REFERENCES}

[APHA] American Public Health Association. 2005. Standard Methods for the Examination of Water and Wastewater. Washington DC: American Public Health Association.

Avnimelech Y. 2012. Biofloc Technology. Baton Rouge: World Aquaculture Society.

Baras E, Raynaud T, Slembrouck J, Caruso D, Cochet C, Legendre M. 2011. Interaction between temperature and size on the growth, size heterogeneity, mortality and cannibalism in cultured larvae and juveniles of the Asian catfish Pangasianodon hypophthalmus (Sauvage). Aquaculture Research 42: 260276.

Crab R, Kochva M, Verstraete W, Avnimelech Y. 2009. Bio-flocs technology application in overwintering of Tilapia. Aquaculture Engineering 40: 105-112.

Crab R, Chielens B, Wille M, Bossier P, Verstraete W. 2010. The effect of different carbon sources on the nutritional value of bioflocs, a feed Macrobrachium rosenbergii postlarvae. Aquaculture Research 41: 559-567.

Crab R, Defoirdt T, Bossier P, Verstraete W. 2012. Biofloc technology in aquaculture: Beneficial effects and future challenges [review]. Aquaculture 356-357: 351-356.

de Alvarenga ER, de Sales SCM, de Brito TS, Santos CR, Correa RDS, Alves GFDO, Manduca LG, Turra EM. 2017. Effect of biofloc technology on reproduction and ovarian recrudescence in Nile tilapia. Aquaculture Research 00: 1-8.
Ekasari J. 2009. Bioflocs technology: theory and application in intensive aquaculture system. Jurnal Akuakultur Indonesia 8: 117-126.

Ekasari J, Crab R, Verstraete W. 2010. Primary nutritional content of bio-flocs cultured with different organic carbon sources and salinity. HAYATI Journal of Biosciences 17: 125-130

Ekasari J. 2014. Biofloc technology as an integral approach to enhance production and ecological performance of aquaculture [Dissertation]. Belgium (BE): Ghent University.

Ekasari J, Angela D, Waluyo SH, Bachtiar T, Surawidjaja EH, Bossier P, de Schryver P. 2014. The size of biofloc determines the nutritional composition and the nitrogen recovery by aquaculture animals. Aquaculture 426-427: 105-111.

Ekasari J, Rivandi DR, Firdausi AP, Surawidjaja EH, Jr MZ, Bossier P, de Schryver P. 2015. Biofloc technology positively affects Nile tilapia Oreochromis niloticus larvae performance. Aquaculture 441: 72-77.

Emilie C, Bénédicte L, Liet C, Jean G, Hervé LD, Chantal C. 2016. Biofloc contribution to antioxidant defence status, lipid nutrition and reproductive performance of broodstock of the quality of eggs and larvae. Aquaculture 452: 252-262.

Ju ZY, Forster I, Conquest L, Dominy W, Kuo WC, Horgen FD. 2008. Determination of microbial community structures of shrimp floc cultures by biomarkers and analysis of floc amino acid profiles. Aquaculture Research 39: 118-133.

Kamilya D, Debbarma M, Pal P, Kheti B, Sarkar S, Singth ST. 2017. Biofloc technology application in indoor culture of Labeo rohita (Hamilton, 1822) fingerlings: the effect on inorganic nitrogen control, growth and immunity. Chemosphere 182: 8-14.

Lara G, Krummenauer D, Abreu PC, Poersch LH, Jr WW. 2016. The use of different aerators on Litopenaeus vannamei biofloc culture system: effects on water quality, shrimp growth and biofloc composition. Aquaculture International 25: 147-162.

Lawson TB. 1995. Fundamental of Aquaculture Engineering. New York (USA): Springer Science \& Business Media.

Long L, Yang J, Li Y, Guan C, Wu F. 2015. Effect of biofloc technology on growth, digestive enzyme activity, hematology, and immune response of genetically improved farmed tilapia Oreochromis niloticus. Aquaculture 448: 135-141. 
Masser MP, Rakocy J, Losordo TM. 1992. Recirculating aquaculture tank production systems-management of recirculating systems. http://darc.cms.udel.edu/AquaPrimer/ recircmgmt.pdf. [30 April 2016].

May RD, Hernandez JM, Leyva EG, Lopez GRP. 2011. Effect of ration and size heterogeneity on harvest time: Tilapia culture in Yucatan, Mexico. Aquaculture Economics \& Management 15: $278-301$.

Murjani A. 2011.Some variety aquaculture three spot goramy Trichogaster trichopterus (Pall) with the provision of commercial feed. Fish Scientiae 1: $214-230$.

Takeuchi T. 1988. Laboratory work-chemical evaluation of dietary nutrients. Fish nutrition and mariculture. Japan: Japan International Cooperation Agency (JICA).

Tucker CC, Robinson EH. 1990. Channel catfish farming handbook. New York (USA): Springer Science \& Business Media.

Wei YF, Liao SA, Wang A. 2016. The effect of different carbon sources on the nutritional composition, microbial community and structure of bioflocs. Aquaculture 465: 88-93. Xu WJ, Pan LQ. 2012. Effects of biofloc on growth performance, digestive enzyme activity and body composition of juvenile Litopenaeus vannamei in zero-water exchange tanks manipulating $\mathrm{C} / \mathrm{N}$ ratio in feed. Aquaculture 356-357: 147-152.

Xu WJ, Pan LQ. 2013. Enhancement of immune respone and antioxidant status of Litopenaeus vannamei juvenile in biofloc-based culture tanks manipulating high $\mathrm{C} / \mathrm{N}$ ratio of feed input. Aquaculture 412-413: 117-124.

Zhao P, Huang J, Wang XH, Song XL, Yang CH, Zhang XG, Wang GC. 2012. The application of bioflocs technology in high-intensive, zero exchange farming system of Marsupenaeus japonicus. Aquaculture 354-355: 97-106.

Zweig RD, Morton JD, Stewart MM. 1999. Source water quality for Aquaculture: A guide for assessment. Washington D.C (USA): The World Bank. 